\title{
13 \\ ANALYSING THE ROLE OF TAX INCENTIVES FOR DONATIONS TO NON-PROFIT ORGANISATIONS IN INDIA
}

\author{
Malini Chakravarty and Priyadarshini Singh
}

\section{Introduction}

The recent amendments (October 2020) to India's Foreign Contributions Regulation Act (FCRA) are among the many challenges confronting the non-profit sector in the country. The act places significant hurdles to the receipt and utilisation of foreign donations by Indian NPOs. This development corresponds to similar global trends of increasing legal and regulatory hurdles on NPOs over the last decade, in both the world's most advanced economies and the developing countries facing the most complex civil strife and public health crises. Therefore, the current COVID-19 pandemic could not have been a more telling context for demonstrating the critical role of non-profits in supporting governments and citizens. Moreover, the pandemic has brought to light the discouraging regulatory environment in which NPOs operate worldwide.

Tax incentives are a key regulatory mechanism surrounding the non-profit sector, whose role is receiving increasing visibility during the pandemic. For instance, Russia, which did not initially provide any tax incentives for charitable donations, now allows a $1 \%$ tax break to businesses donating a portion of their profits to charity (CAF America, 2021). China has also significantly increased its tax incentives for philanthropic activities (Lexology, 2020). However, India has not increased tax incentives for donations to the non-profit sector, despite its pandemic-induced fund shortage in the last year. A study by Dasra (2020), a leading non-profit sector advisory and research organisation, highlights that there is likely to be significant reduction both in short and long term funding to the sector. Funding from corporate social responsibility (CSR) channels may see a long-term reduction as almost 2000-3000 crore INR will get redirected to the COVID-19-focused PMCARES fund ${ }^{1}$. Corporates are also likely to register a plunge in their profits and subsequently affect the funds they channel to their CSR contributions for the sector. Large donations from ultra-high net worth individuals (UHNWIs) may fall in the short term due to stock market volatility.

At a time when the Indian government has significantly relied on NPOs during the pandemic, it has not made any effort to ease their regulatory environment, particularly regarding funding and tax incentives. On the one hand, since March 2020, NITI Aayog, the apex national-level policy planning body of the government of India, has formally collaborated with 92,000 non-governmental organisations (NGOs) (Kulkarni, 2020) to manage socio-economic 
challenges. On the other hand, new hurdles have been placed in accessing funding. Foreign funding will be hard to access because of the recent amendments in the FCRA. Recent changes in the tax regime for individuals and corporates allow donors to voluntarily opt out of tax incentives for philanthropic giving to benefit from lower rates of personal and corporate income tax.

Systematic studies on the role of tax incentive regimes as a whole and their contribution to strengthening the non-profit sector (and through that the national community), as well as their cost to the public exchequer, are limited, particularly in the Indian context.

A preliminary attempt to address this lacuna is being undertaken in a study by the Centre for Social Impact and Philanthropy (CSIP) at Ashoka University, Sonipat, in a research partnership with the Centre for Budget and Governance Accountability (CBGA) in Delhi. The study reviews the tax incentive structures of 12 select countries, including India, ${ }^{2}$ evidence of their impact in encouraging philanthropic activities.

This chapter draws from the aforementioned project's findings. Centring around the Indian case, the study examines three critical aspects of tax incentives for charitable donations to NPOs. First, to what extent do tax incentives support the non-profit sector financially and legally? Second, what is the cost of such tax incentives for philanthropy to the Indian exchequer as a share of personal and corporate income tax collected? Third, how do the design and scope of the Indian tax incentives compare with other countries/the rest of the world? Overall, this chapter aims to provide policy recommendations to the Indian government for strengthening its tax incentive regime for philanthropic giving.

We address our research questions using a mix of qualitative and quantitative methods. To examine the financial and legal role of tax incentives, we examined the existing quantitative databases and research reports on the sources of financial inflows and their adequacy to the nonprofit sector. Regarding the impact of tax incentives on public revenue, we analysed the data on the foregone revenues reported by the Indian government over 13 years from 2006-2019. Next, drawing on the previously mentioned tax incentives review project, we conducted the cross-country comparative review of the tax incentive regime in India. Additionally, we also reviewed secondary documents such as government and civil society reports as well as academic literature on the evidence of the impact of tax incentives on philanthropy. We validated our findings from the secondary document review by consulting tax and civil society experts and academics based in all the study countries except Norway and China. For these countries, our analysis relies entirely on secondary documents. All the material reviewed in this chapter is available in the public domain and mainly written in English. We commissioned French and Portuguese translations of some academic research set in France and Brazil. The language barrier in non-English-speaking countries was addressed by conversations with experts from these countries. Nonetheless, the limited access to the literature in the country's national languages is a limitation of this work.

The chapter is organised around our three research questions. In Section 1, we examine the financial and non-financial contribution of tax incentives in India. Here we argue that while the funds flowing into the sector due to tax incentives are minimal compared to those coming in from other sources, they are a prominent source of financial and legal legitimacy for this sector in India. Due to their small size and limited capacities, most NPOs lack access to alternative funding sources. In Section 2, we discuss India's tax incentive structure and present the trends in the revenue foregone by the Indian government. We illustrate that the revenue lost due to tax incentives for philanthropic giving is negligible. In Section 3, we present the global evidence on the state of tax incentives. We show that compared to other countries, India has a conservative tax incentive regime for philanthropic giving and is among the few countries without documented evidence on the effectiveness (or the lack) of tax incentives. Finally, in Section 4, we 
provide policy recommendations for strengthening the Indian tax incentive regime to increase philanthropic giving.

\section{Tax incentives and India's non-profit sector: financial and regulatory environment}

India lacks accurate and recent official data on its non-profit sector in terms of the number of NPOs, the nature of their work, their size, and the source of their financial inflows. The Darpan portal is an online, publicly accessible database established by the government of India where any Indian NPO applying for government grants-in-aid, and those receiving international funding, must register. However, it does not cover NPOs that do not use government or international grants. The portal provides a broad cross-section of data on the non-profit sector covering many thematic areas (such as health, education, skills, and livelihoods), service areas (advocacy, service delivery), and information on the quantum of grants-in-aid received. However, the quality of the data on the portal is poor. Other databases on the sector are in the context of legal and regulatory provisions such as the Income Tax Act, FCRA, and the Companies Act. These databases cover only a small subset of Indian NPOs and provide only the number of NPOs registered under these acts, leaving out other relevant information such as the area of work or the nature of their activities.

Our analysis of the financial and regulatory role of tax incentives draws on three major studies that provide an overview of the non-profit sector in India. The Indian Ministry of Statistics and Planning (MOSPI) in 2012 conducted a census-like exercise of the non-profit sector in line with the UN handbook on Non-profit Accounting. The study, however, focused only on those NPOs which are registered as 'societies', which is one of the three legal forms for the registration of NPOs in India. The other two are 'trusts' and 'Section 8' companies. This study reports that India has approximately 3.1 million registered 'societies' in India. ${ }^{3}$ Of these, a little over half a million societies were physically 'traced' by the MOSPI study researchers. The detailed overview of the non-profit sector provided in the study includes data on the state-wise location of the traced societies, their operational areas (such as health, education, social service), and rural-urban distribution and funding sources. The second study was recently undertaken by the CSIP to understand the state of the support ecosystem available to the non-profit sector in India dealing with aspects such as fundraising, monitoring and evaluation, accounting, and communications. The study included 800 NPOs and 65 foundations (grant-making bodies) across India, using an online survey on 3,500-plus verified NPOs registered with GuideStar India. ${ }^{4}$ The profile of the sampled NPOs gives a snapshot of the non-profit sector and includes indicators such as their state-wise location, thematic operation areas, and operating budgets. The third study was also undertaken by the CSIP, and it examined the total capital in the non-profit sector from various sources, including tax-incentivised donations, corporate social responsibility and foreign contributions (CSIP, 2020).

These reports highlight three distinct aspects of the non-profit sector in India. First, the sector is dominated by small NPOs. The CSIP study ${ }^{5}$ of the non-profit ecosystem is the only one that provides a breakdown of the sample NPOs based on their operating budgets. The study estimates that over half of the sampled NPOs ${ }^{6}$ have an annual operating budget of up to approximately 68,000 $\mathrm{USD}^{7}$ approx. (less than INR 50 lakhs) a year. Additionally, $15 \%$ of the sampled NPOs have an annual operating budget of only up to 6,804 USD (up to INR 5 lakhs a year) (see Figure 13.1).

Second, the NPOs' focus areas as well as their geographical spread are disproportionately skewed. The CSIP study highlights that most NPOs are concentrated in the areas of education (with 75\%) and health (with 65\%) ${ }^{8}$ (CSIP, 2019). However, within these thematic areas, there 


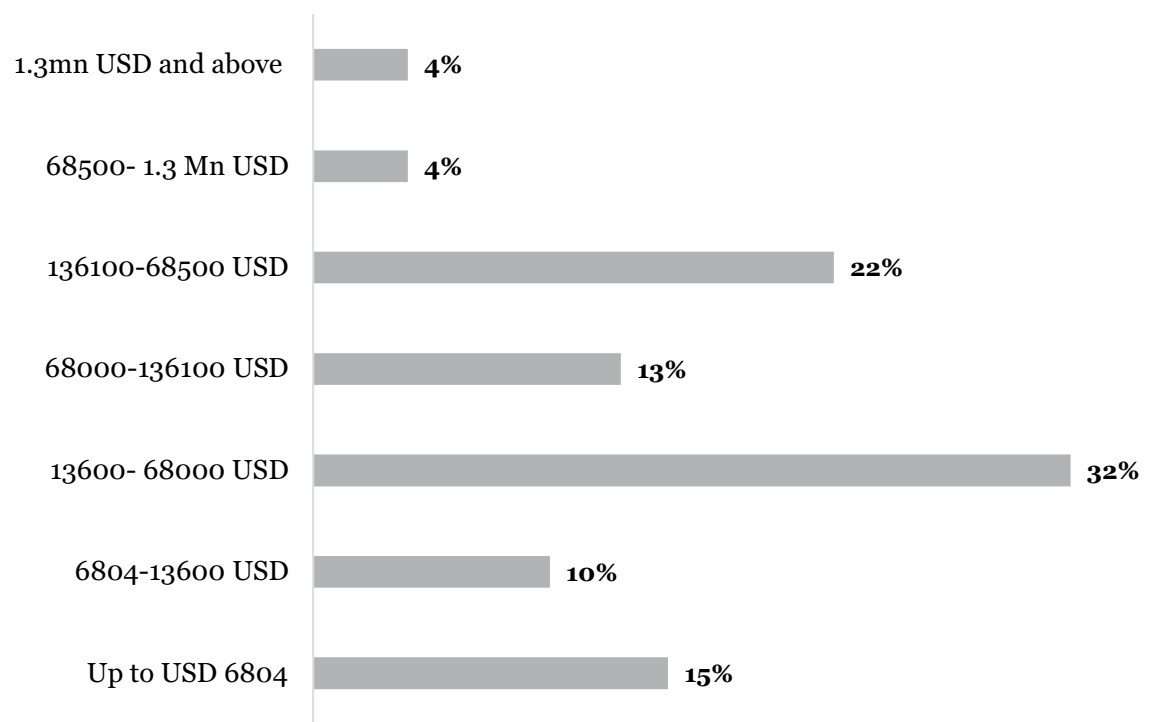

Figure 13.1 Distribution of NPOs in study sample according to the operating budget (in USD)

Source: (CSIP, 2019) Conversion rate 1 USD $=73$ INR

Note: Lower and outer limit has been kept out of the estimates.

is no data available on the exact nature of the work undertaken by the NPOs, for example, whether it is service delivery, advocacy, or communications. Conversations with experts in the sectors highlight that the majority of the NPOs focus on service delivery activities, with relatively few working on research and advocacy. Maharashtra and Uttar Pradesh are the top states where the maximum number of sampled NPOs are located. Similarly, the MOSPI study highlights that more than $82 \%$ of the traced societies are registered in 24 states (this list excludes large states such as Rajasthan and Maharashtra). Of these, Uttar Pradesh, the most populous Indian state, has $37 \%$ of the traced societies. Andhra Pradesh (undivided; includes Telangana) has the second-highest population and only $11 \%$ of the traced societies. Bihar, another populous and poor Indian state, has only $0.6 \%$ of the traced societies (MOSPI, 2012, pp. 6-70). The concentration of NPOs in a limited number of thematic areas and states, and the availability of better funding opportunities through varied sources such as CSR, mutually reinforce each other. That is to say, as more NPOs work in certain sectors/issue areas, more funding flows into those specific areas than others and vice versa.

Third, tax-incentivised donations constitute the smallest share of funding sources into this sector as highlighted by the CSIP study (2018). Table 13.1 presents the share of individual and corporate donations incentivised through tax incentives ( $\mathrm{d} 1$ and $\mathrm{d} 3$ ), which is much lower than other funding sources such as CSR funds (C), foreign contributions (A), and informal everyday giving (E). ${ }^{9}$

The data available on the non-profit sector indicates that an accurate assessment of the financial and legal role of tax incentives is highly difficult. However, the role of the tax incentives may be critical because of the specific nature of the Indian non-profit sector. For many NPOs, their operating budgets are low, and they operate from geographically remote areas. Consequently, they have limited resources to communicate the impact of their work or seek assistance of support organisations for communication, fundraising, and so on. In this context, a tax exemption 
Table 13.1 Philanthropic capital flowing in the Indian NPO sector (in USD millions)

\begin{tabular}{|c|c|c|c|}
\hline S. No. & Philanthropic source & $2017-18$ & Source \\
\hline A. & Foreign contribution & 2289 & www.fcraonline.nic.in \\
\hline B. & $\begin{array}{l}\text { Grants-in-aid to NGOs listed } \\
\text { on DARPAN portal }\end{array}$ & 1428 & https://ngodarpan.gov.in/ \\
\hline C. & Grants through CSR Act & 18582 & https://csr.gov.in/CSR/ \\
\hline D. $(\mathrm{d} 1+\mathrm{d} 2+\mathrm{d} 3)$ & $\begin{array}{l}\text { Formal giving (income tax } \\
\text { deductions }{ }^{\star} \text { claimed on } \\
\text { account of donations } \\
\text { to charitable trusts and } \\
\text { institutions) }\end{array}$ & 315 & $\begin{array}{l}\text { https://www.indiabudget.gov.in/ } \\
\text { budget2018-2019/ub2018-19/ } \\
\text { rec/annex7.pdf }\end{array}$ \\
\hline d1 & Corporate taxpayer & 215 & \\
\hline $\mathrm{d} 2$ & $\begin{array}{l}\text { Non-corporate taxpayers } \\
\text { (firms/associations of persons } \\
{[\text { AOPs]/body of Individuals }} \\
[\mathrm{BOI}])^{\star \star}\end{array}$ & 16 & \\
\hline $\mathrm{d} 3$ & $\begin{array}{l}\text { Individuals/Hindu undivided } \\
\text { family (HUF) taxpayers }\end{array}$ & 82 & \\
\hline E. & $\begin{array}{l}\text { Everyday/informal giving by } \\
\text { individuals } \star \star \star\end{array}$ & 4178 & $\begin{array}{l}\text { Report: 'Everyday Giving in India' } \\
\text { by Sattva Consulting: https:// } \\
\text { www.sattva.co.in/publication/ } \\
\text { research-everyday-giving-in- } \\
\text { india-report/ }\end{array}$ \\
\hline
\end{tabular}

Source: Internal note prepared by CSIP, 2020 (reproduced here with permission)

* This is the sum total of amounts sanctioned by the central and state government to the NGOs registered on Darpan.

$\star \star$ This indicates the income tax deductions claimed by corporate, non-corporates, and individuals/ HUF on account of donations to charitable trusts and institutions under section 80G. It is difficult to ascertain the total charitable contributions made, as the IT deduction claimed is a function of the tax bracket the taxpayers fall into, the deduction they are eligible for (50\% versus $100 \%$ deduction), and the actual donation amount made by the taxpayer. Since individual charitable contribution data are not available at a disaggregate level, we cannot comment on the total charitable contributions made by these taxpayers.

$\star \star \star$ A report by Sattva Consulting estimated that $90 \%$ of India's everyday giving is informal and largely in cash; it is mostly targeted to community members such as domestic helpers, homeless, and religious or spiritual institutions.

certificate provides legal legitimacy to NPOs and recognition of their work, including for those donors who do not seek to claim tax exemptions. Last, though tax incentives provide lower capital inflows to the sector compared to other sources, they remain the primary source of funding for a vast majority of NPOs that do not have access to foreign or CSR funds. Therefore, for these NPOs, even the limited funding support provided by tax incentives may be significant. However, a systematic study of these varied roles played by tax incentives in the non-profit sector is critical.

\section{Does India's tax incentive structure encourage philanthropic giving towards NPOs?}

India has a long history of tax incentives for philanthropic giving, which dates back to the British Raj (Sampradaan Indian Centre for Philanthropy, 2004). However, the basic structure of the 
tax incentive has remained unchanged since the mid-1970s and has seen a noticeable dilution in recent years. Moreover, the current tax incentive regime is designed to disproportionately incentivise philanthropic donations to government entities. The recent changes in the tax structure have either expanded the remit of philanthropic donations to the government or removed some incentive provisions for donating to NPOs.

There are two main provisions for tax incentives for philanthropic donations detailed in the Indian Income Tax Act, 1960. Under Section 80G, individuals and corporations are eligible to receive two categories of tax deductions, $100 \%$ and $50 \%$, on donations given to government entities, government-run funds, trusts, societies, and other bodies that possess an $80 \mathrm{G}$ certificate (Puri, Nayak, and Dadrawala, 2018). Under Section 80GGA, donations can also be made for scientific research or rural development (Srinath, 2003). Section 80G is the broader and most widely used tax incentive provision, and under it, the donations made to government entities have the highest incentives. Donations made to NPOs attract only a 50\% tax deduction, along with a ceiling. Other than this, since the financial year (FY) 2015, three main government programmes have been granted 100\% donor exemption status under Section 80G. These are the 1) Swachh Bharat Abhiyan, 2) Clean Ganga Campaign, and 3) National Fund for Drug Abuse (VANI, 2016). Table 13.2 presents a summary of the $80 \mathrm{G}$ tax provisions for donations to NPOs and government entities.

Donations made under 80GGA (Srinath, 2003), while being fully deductible, apply only to institutions undertaking scientific, social science, or statistical research or rural development. Additionally, each institution eligible for a donation must be approved by the government under Section 35 (1) ii of the Income Tax Act. Moreover, here as well, the list of institutions eligible for donations under this section includes government entities and funds, such as public-sector companies, government-notified funds for rural development and afforestation, and a national fund for poverty eradication.

The 35AC tax incentive provision was introduced in the 1990s, which aimed to promote corporate donations. Under the provision, unlike the certificate granted under Section $80 \mathrm{G}$ (wherein donations made to qualifying NPOs entitles a donor to a $50 \%$ tax deduction), the $35 \mathrm{AC}$ certificate is given to NPOs running government-approved projects (Agarwal and

Table 13.2 Summary overview of India's tax incentive structure for philanthropy

\begin{tabular}{|c|c|c|c|}
\hline Tax deduction & Ceiling & Nature of entity & Examples \\
\hline $100 \%$ & None & $\begin{array}{l}\text { Central government funds } \\
\text { and entities and some state } \\
\text { government entities/funds }\end{array}$ & $\begin{array}{l}\text { * National Defence Fund } \\
\text { ^ Prime Minister's } \\
\text { National Relief Fund }\end{array}$ \\
\hline $50 \%$ & None & $\begin{array}{l}\text { Central and state government } \\
\text { funds and entities and some } \\
\text { government entities/funds }\end{array}$ & $\begin{array}{l}\text { ^ Jawaharlal Nehru Fund } \\
\text { ^ Prime Minister's } \\
\text { Drought Relief Fund }\end{array}$ \\
\hline $100 \%$ & $\begin{array}{l}10 \% \text { of the adjusted } \\
\text { gross total income }\end{array}$ & $\begin{array}{l}\text { Central government funds } \\
\text { and entities and some state } \\
\text { government entities/funds }\end{array}$ & $\begin{array}{l}\text { * Government entities } \\
\text { involved in family } \\
\text { planning } \\
\text { * Government entities } \\
\text { involved in Olympic } \\
\text { association }\end{array}$ \\
\hline $50 \%$ & $\begin{array}{l}10 \% \text { of the adjusted } \\
\text { gross total income }\end{array}$ & $\begin{array}{l}\text { Non-profit organisations } \\
\text { (known as civil society } \\
\text { organisations) }\end{array}$ & $\begin{array}{l}\text { All NPOs with an } 80 G \\
\text { certificate }\end{array}$ \\
\hline
\end{tabular}


Dadrawala, 2004) in areas such as drinking water projects, building homes for the poor, and building schools in economically vulnerable areas. While the provisions allowed the donors to deduct the full value of their donations against their taxable income, the exemptions were placed for a specific list of projects approved by the central government (VANI, 2016). This provision was, however, revoked in 2016-17.

In 2020, the tax incentives for philanthropic donations received further pushback by the Indian government with the introduction of a new 'optional' tax regime for individual and corporate taxpayers in the Union Budget 2020-21. Under this provision, individual taxpayers can avail themselves of lower tax rates if they forgo most of the tax incentives, including those for donations. Similarly, corporates who forgo tax incentives and exemptions are eligible for a reduction in the base tax rate to $22 \%$ from 30\% (Rajakumar and Shetty, 2020). ${ }^{10}$ While both these rules are optional at present, given that they entail an option of transitioning to a lower tax slab, it has far-reaching implications for tax incentives for philanthropic giving.

India's overall taxation policy, especially the changes in marginal tax rates since globalisation (i.e., the mid-1980s, when India began opening up to the world economy), further limits the attractiveness of the restricted tax incentives for donations to NPOs. As several experts note, tax reforms involving a reduction in marginal tax rates adversely affect donors' incentives for philanthropic giving (Clotfelter, 2012), unless these are compensated for with other incentives for inducing generous contributions. Therefore, analysing the marginal tax rate trends as part of a country's tax incentive regime is crucial for understanding the benefits derived by the donors and hence their incentive to give. Similar to many other countries across the world, India, too, since the mid-1980 $\mathrm{s}^{11}$ has seen a reduction in the marginal rates of personal income tax (PIT) and corporate income tax $(\mathrm{CIT})^{12}$ (see Figure 13.2 for peak PIT rates). In addition to these cuts, taxes affecting high-income groups such as the inheritance and wealth taxes, were also abolished in the 1980s and 2000s ${ }^{13}$ (Rao and Rao, 2006).

The lower tax rates introduced for PITs in 1997-98 continue to date with three modifications: a) an increase in the number of tax brackets with the lowest marginal tax rate starting at $5 \%$ from the earlier 10\% (as part of tax regime for individual taxpayers introduced in the Union Budget 2020-21); b) introduction of and thereafter increases in surcharge and cesses dedicated

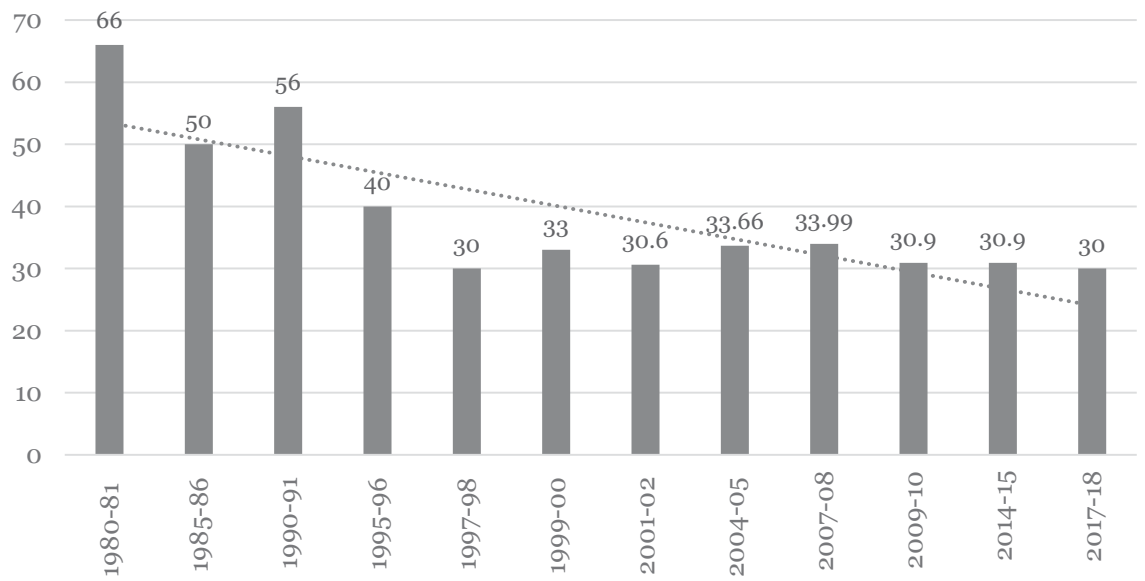

Figure 13.2 Trend in the peak rates of individual income tax (in \%)

Source: Indian Public Finance Statistics, Ministry of Finance, various years 
to primary education and health, ${ }^{14}$ (Rao and Rao, 2006); and c) higher surcharges levied on the super-rich (since the Indian Union Budget 2019-20) (CBGA, 2019)..$^{15}$

Unlike the trends in PIT rates (which have stabilised and even increased to an extent) CIT rates in India have continued to register significant cuts, even in the recent years. Thus, in 1985-86, the peak corporate tax rate was reduced from around $60 \%$ to $50 \%$, further reducing to $45 \%$ in 1994-95, 30\% in 2005-06 (Pattnaik, 2009), and finally to $25 \%$ for existing companies as of $2019^{16}$ and $15 \%$ for manufacturing companies established after October 2020 (Ministry of Finance, 2020).

However, the decline in tax rates in India did not accompany corresponding measures to increase tax incentives for charitable donations, thereby reducing their attractiveness over time (Viswanath and Dadrawala, 2004). Recent changes have in fact diluted the tax incentives for philanthropic donations.

\section{Are tax incentives for philanthropic donations costly to the Indian government?}

India is one of the lowest-taxed countries in the world, with the total (union plus state) tax to gross domestic product ratio being as low as $18 \%$ in 2020. Several experts suggest reducing the tax incentives ${ }^{17}$ (including for philanthropic donations) to broaden the country's tax base and increase the potential tax revenue. However, regarding tax incentives for philanthropic donations to NPOs, it is important to assess whether the potential revenue generated by the withdrawal of tax incentives is large enough to warrant their removal. It is highly likely that the potential revenue generated from such a withdrawal may be negligible compared to the adverse impact on the functioning of the non-profit sector. As shown in Figure 13.3, the revenue foregone from individual and corporate donations as shares of PIT and CIT collections, respectively,

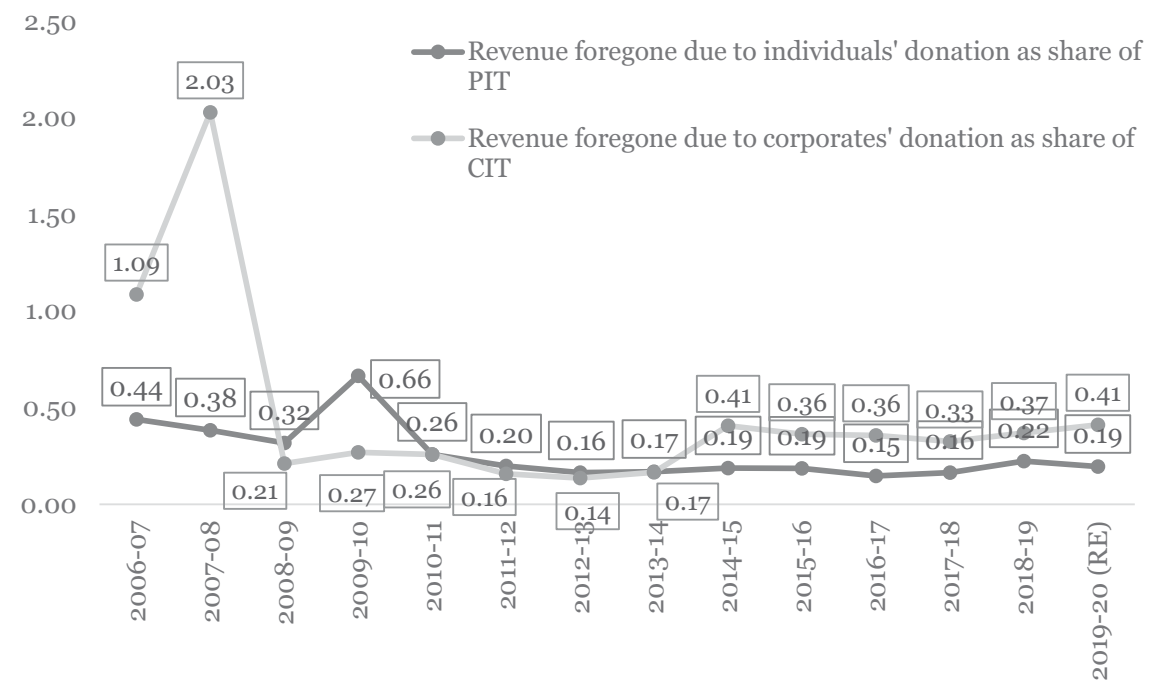

Figure 13.3 Revenue foregone on account of deductions claimed on donations by individuals and corporate taxpayers as a percentage of their respective tax revenues

Source: Author's calculation based on the Receipt Budget, Union Budget documents, various years

Note: RE: Revised estimate; the rest of the figures denote the actuals. 


\section{Chakravarty and Singh}

are quite small. Further, in the case of individual taxpayers, this share has consistently remained lower than the high reached in 2009-10. Revenue foregone on account of corporate donations as share of corporate income tax collection has returned to the high registered in 2014-15, but it still remains much below $1 \%$ of corporate income tax revenue collected.

Notably, the revenue foregone figures provided by the government are aggregate figures, which do not segregate between revenue foregone on account of donations to government entities and funds or donations to the NPOs. Given that the former attracts a more generous tax deduction, the revenue foregone on account of donations to NPOs is likely to be much lower than the aggregate figures cited in the budget documents.

The combined revenue lost due to tax incentives for philanthropic donations by both individual and corporate donors over the last decade (see Figure 13.4) constitutes less than $2 \%$ of total revenue foregone on income tax collection.

Given this context, the move towards a blanket removal of all types of incentives, without undertaking an in-depth cost-benefit analysis of their effectiveness against their basic objectives, does seem somewhat arbitrary. However, there is an acute lack of such literature in the case of philanthropic donations. The few studies available are dated and of little relevance for the present context when marginal tax rates for individuals and corporates have declined significantly (Aggarwal, 1989; GOI, 2001). Furthermore, there is a lack of publicly accessible data on the amount of donations, making a rigorous analysis of the implications for philanthropic activities in India difficult.

The previous analysis shows that with globalisation, while India's taxation strategy has seen a significant change, its tax incentive framework for charitable donations has either remained static (for the most popular tax incentive scheme under Section 80G) or has been completely dismantled (as in the case of the tax incentive under Section 35AC). Consequently, the benefit donors can derive from such tax incentives has shrunk over time. The analysis of the data on revenue foregone indicates that phasing out of tax incentives for charitable donations is unlikely to generate substantial additional potential revenue for the state exchequer. Such a move, however, is likely to have a disproportionately adverse impact on NPOs by blocking a major funding source.
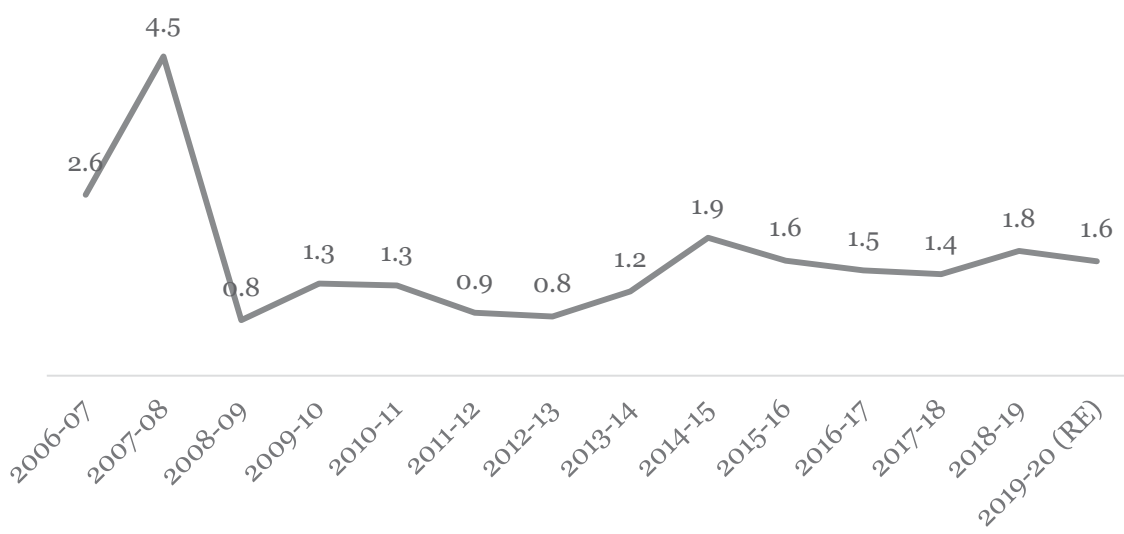

Figure 13.4 Revenue foregone on account of philanthropic donations as a percentage of revenue foregone on PIT and CIT

Source: Author's calculation based on the Receipt Budget, Union Budget documents, various years

Note: RE: Revised estimate; the rest of the figures denote the actuals. 


\section{India's tax incentives and their impact on philanthropy: a global overview}

Compared to the 11 countries we studied in our project, India's tax incentive regime can be characterised as conservative in what we define as its 'provision' and 'scope'. Unlike countries such as Brazil, India's tax incentives for philanthropic donations do not disincentivise philanthropy; however, the existing structure does not prioritise tax incentives as an instrument to facilitate donations. The tax incentive structures of the 12 study countries (including India) are analysed under the 'provisions' of these incentives, which refers to the specific mechanisms for providing incentives on individual incomes and assets, and business income. We also examine it on the 'scope' of the incentives, which includes the rates of incentives, ceilings, and the sectors eligible for charitable giving.

\section{Provisions of tax incentives}

As presented in Table 13.3, our study countries have three forms of tax incentives on personal income tax (PIT), namely deductions, credit, and grossed-up donation. Deductions are the most common form and are available in all the study countries, except France and South Korea. In these two countries, tax incentives are given in the form of credit. The United Kingdom is a unique case, with two forms of incentives, deductions and grossed-up donations. India provides tax incentives on both personal and corporate income tax channelled only through standard deductions. The form of tax incentives influences charitable donations in important ways. Credits reduce the tax outflow of donors more than deductions. ${ }^{18}$ Grossed-up donations are most beneficial to high-income donors, giving them the maximum reduction in tax outflows. ${ }^{19}$ In a

Table 13.3 Summary of tax incentive provisions on personal income tax, individual assets, and cross-border donations

\begin{tabular}{|c|c|c|c|c|c|c|c|c|}
\hline Countries & Deductions & Credit & Grossed-up & $\begin{array}{l}\text { Inheritance } \\
\operatorname{tax}\end{array}$ & $\begin{array}{l}\text { Wealth } \\
\text { tax }\end{array}$ & $\begin{array}{l}\text { Capital } \\
\text { gains tax }\end{array}$ & $\begin{array}{l}\text { Donation/ } \\
\text { gift Tax }\end{array}$ & Cross-border \\
\hline United States & Yes & & & Yes & & Yes & & Yes \\
\hline UK & Yes & & Yes & Yes & & Yes & & Yes \\
\hline China & Yes & & & & & & & \\
\hline South Africa ${ }^{1}$ & Yes & & & Yes & & & Yes & Yes \\
\hline Singapore & Yes & & & & & & & \\
\hline Norway & Yes & & & & & & & Yes \\
\hline Brazil & Yes & & & Yes & & & Yes & \\
\hline Mexico & Yes & & & & & & & Yes \\
\hline India & Yes & & & & & & & \\
\hline Bangladesh & Yes & & & & & & Yes & Yes \\
\hline South Korea & & Yes & & Yes & & & & Yes \\
\hline France & & Yes & & Yes & Yes & & & Yes \\
\hline
\end{tabular}

Source: Based on Report on the State of Tax Incentives across the 12 countries under finalisation by CBGA and CSIP

1 Only businesses are allowed to make cross-border donations. 


\section{Chakravarty and Singh}

grossed-up donation-based approach, charities get greater monetary benefit as compared with deductions or credit-based provisions. Grossed-up donations seem to prioritise High Net Worth Individuals (HNWIs), as they are the most responsive to tax incentives. ${ }^{20}$ For small donors, grossed-up donations provide greater worth to the monetary value of the donations they make. The government monetarily matches the amount donated to a charity, so for every amount donated, the charity receives an equal amount from the government, also increasing the value of the donation made. The use of either of these forms would significantly enhance the impact of tax incentives in India.

Furthermore, as Table 13.3 highlights, India does not have any of the other taxes (other than capital gains tax); hence, there are no incentives on those, examples being wealth tax, estate duty, or inheritance tax. The gift tax is applicable in India, Bangladesh, Brazil, and South Africa, which is included under the donation tax. However, only India does not provide an incentive for philanthropy on gift tax. It is also among the four sample countries (the others are China, Brazil, and Singapore) that do not provide incentives for cross-border donations.

\section{Scope of tax incentives}

Tax incentive provisions are primarily defined by their scope of implementation and are effective only when their scope targets a wide range of donors and philanthropic causes. The scope of tax incentives on individual incomes, assets, donations, and corporate taxes depends on factors such as the rate of incentives, the ceiling on income and the tax payable, and the eligibility of the sectors. Table 13.4 highlights the rate of incentives and the ceilings applicable on PIT in the study countries and shows that India is the only country that incentivises donations to government entities over and above NPOs. Most countries have implemented 100\% incentives for NPOs with some ceilings, whereas India (along with two other countries) offers tax incentives at less than $100 \%$ with ceilings.

Table 13.4 Summary of tax incentives rates on personal income tax and applicable ceilings

\begin{tabular}{llll}
\hline Country & Form & Rate of incentives & Ceiling (income and tax payable) \\
\hline Singapore & Deduction & $250 \%$ & No limit \\
UK & $\begin{array}{l}\text { Deduction and } \\
\text { grossed up }\end{array}$ & $100 \%$ & $100 \%$ of tax payable \\
USA & Deduction & $100 \%$ & $60 \%$ of taxable income \\
China & Deduction & $100 \%$ & $30 \%$ of taxable income \\
S. Africa & Deduction & $100 \%$ & $10 \%$ of taxable income \\
Brazil & Deduction & $100 \%$ & $8 \%$ of tax payable with charity area-based exemptions \\
Mexico & Deduction & $100 \%$ & $7 \%$ of previous year's taxable income \\
Norway & Deduction & $100 \%$ & NOK 50,000 \\
India & Deduction & $50 \%, 100 \%$ & $10 \%$ of taxable income in most cases, $100 \%$ when \\
& & & donating to select government funds and entities \\
Bangladesh & Deduction & $15 \%$ & Maximum donation allowed is $30 \%$ of taxable \\
& & & income or BDT 15 million, whichever is lower \\
France & Credit & $66 \%, 75 \%$ & $20 \%$ of taxable income \\
S. Korea & Credit & $15 \%, 30 \%$ & $100 \%$ of tax payable \\
\hline
\end{tabular}

Source: An interim report on the state of tax incentives across the 12 countries by CBGA and CSIP, 2021 (reproduced with permission) 
Table 13.5 summarises the provisions and the scope for a tax incentive for businesses, revealing that here as well, India is the only country that incentivises donations to government entities.

Table 13.5 Summary of tax incentive rates for businesses

\begin{tabular}{llll}
\hline Country & Form & Rate of incentives & Ceiling (income and tax payable) \\
\hline Singapore & Deduction & $250 \%$ & No limit \\
UK & Deduction & $100 \%$ & $100 \%$ of tax payable \\
S. Korea & Deduction & $100 \%$ & $50 \%$ of taxable income \\
USA & Deduction & $100 \%$ & $30 \%$ of taxable income \\
China & Deduction & $100 \%$ & $12 \%$ of taxable income \\
S. Africa & Deduction & $100 \%$ & $10 \%$ of taxable income \\
Brazil & Deduction & $100 \%$ & $8 \%$ of taxable income \\
Mexico & Deduction & $100 \%$ & $7 \%$ of last year's income \\
Norway & Deduction & $100 \%$ & NOK 50,000 \\
India & Deduction & $50 \%, 100 \%$ & $10 \%$ of taxable income in most cases, $100 \%$ when \\
& & & donating to select government funds and entities \\
Bangladesh & Deduction & $10 \%$ & Maximum donation allowed is $10 \%$ of taxable income \\
& & & or BDT 120 million whichever is lower \\
France & Credit & $60 \%$ & $0.5 \%$ of the annual revenue \\
\hline
\end{tabular}

Source: Report on the State of Tax Incentives across the 12 countries under finalisation by CBGA and CSIP, 2021 (reproduced with permission)

The list of causes eligible for tax incentives further determines the scope of the incentives ${ }^{21}$. India has a moderate range of causes eligible for tax incentives. While it does not include areas such as human rights, it has a generic area called 'objects of general public utility'. While this provision expands the scope of the eligible causes that are incentivised, it also significantly increases the discretionary powers of the government. Table 13.6 presents the most common philanthropic causes eligible for tax incentives among the study countries.

Table 13.6 Common causes eligible for tax incentives across the study countries ${ }^{22}$

\begin{tabular}{|c|c|c|c|c|c|c|c|c|c|}
\hline & Health & Education & $H R^{*}$ & Religion & $\begin{array}{l}\text { Arts/culture/ } \\
\text { heritage }\end{array}$ & Science & $\begin{array}{l}\text { Poverty } \\
\text { reduction }\end{array}$ & Sports & Environment \\
\hline \multicolumn{2}{|l|}{ Bangladesh } & Y & & & & & & & \\
\hline Brazil & Y & & & & & & & Y & \\
\hline China & Y & Y & & & Y & Y & Y & $\mathrm{Y}$ & Y \\
\hline France & Y & Y & & & $\mathrm{Y}$ & Y & & Y & Y \\
\hline India & Y & Y & & & Y & & Y & & Y \\
\hline \multicolumn{10}{|l|}{ Mexico } \\
\hline Norway & Y & & Y & Y & $\mathrm{Y}$ & & & & Y \\
\hline Singapore & Y & Y & & Y & $\mathrm{Y}$ & & Y & $\mathrm{Y}$ & Y \\
\hline South Africa & Y & Y & & & & & & & Y \\
\hline \multicolumn{4}{|l|}{ South Korea } & Y & & & & Y & \\
\hline UK & Y & Y & Y & Y & Y & Y & Y & Y & \\
\hline USA & Y & Y & Y & Y & Y & & Y & & \\
\hline
\end{tabular}

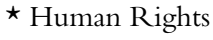




\section{Strengthening India's tax incentive regime: policy recommendations}

India is among the six countries in our study cohort that have some documentation on the impact of tax incentives. But the Indian studies are dated and belong to an era when tax rates were high, which made tax incentives lucrative. Therefore, the recent changes in India's tax incentives regime were implemented without a systematic analysis of their economic, legal, and regulatory impact on civil society. Such a study would provide the foundational step in improving and strengthening the tax incentive regime in India, consequently improving the access to funding in Indian civil society. We strongly recommend that such a study be commissioned by an appropriate government authority.

The best studies on the effectiveness of tax incentives are available in the United States and the United Kingdom. They highlight the strengths and limitations of the evidence generated through such an analysis. The econometric analysis of price elasticities of tax incentives highlights their financial efficacy, although they do not shed enough light on the other roles tax incentives play for civil society. Most studies in this stream of research conclude that the increase in philanthropic giving generated through an increase in tax incentives, is either non-existent or marginal. A key variation is in the price elasticity of different income groups. In the context of France (Fack and Landais, 2010), the United Kingdom (Scharf and Smith, 2009), and the United States (Bijika, 2013; Backus and Grant, 2019), studies estimate higher elasticities for high-income groups, whereas in South Korea (Park and Jeon, 2017) and Singapore (Chua and Wong, 1999), the price elasticity of lower-income groups is higher than that of high-income groups. The characteristics of the dataset used can especially impact the estimates of the price elasticity of tax incentives. The study by Duquette (2016), which uses the data on donations received by charities in the United States, estimates that a $1 \%$ increase in the tax cost of philanthropy leads to a $4 \%$ fall in the donations received by charities. Focusing on the charity data, this study analysed the donations made to religious organisations and organisations with assets valued at less than 100 million USD that are not required to file tax returns. These organisations have been mostly excluded from the datasets used in other studies in the United States. We recommend that an income group-focused study that uses data from both the donors and charity organisations would be well suited to understand the financial impact of tax incentives in India. However, to undertake this study, data availability remains a critical challenge.

Among our study countries, India lacks sufficient data transparency on taxes (others include Bangladesh, China, Mexico, and South Africa) and the scale of donation activities (along with Bangladesh, China, Mexico, South Africa, Singapore, and South Korea), posing serious challenges in conducting a systematic analysis. Without these two data sets, the effectiveness of incentives cannot be understood. The United Kingdom and the United States are the only countries which provide high-quality data for the study of tax incentives. Table 13.7 summarises the types of data available in these two countries and the research analyses they enable from a policy perspective.

We also argue that a comprehensive study on the effectiveness of tax incentives should focus on the other benefits for donations such as legal recognition of the non-profit sector as a whole and individual charities, particularly in remote areas. Tax incentives also establish and anchor the state-civil society relationship through a formal and a historically well-established regulatory channel. While some sections of civil society are informal in nature and outside the regulatory ambit such as that of tax incentives, there is a prominent segment that works with the government in service delivery activities, which could benefit from legal recognition and tax incentives. At a normative level, such recognition of charitable activities enables civil society activism 
Table 13.7 Summary of data required to study tax effectiveness and related research areas

\begin{tabular}{|c|c|c|c|}
\hline Country & Tax data & Scale of donations & Research areas \\
\hline $\begin{array}{l}\text { United } \\
\text { Kingdom }\end{array}$ & 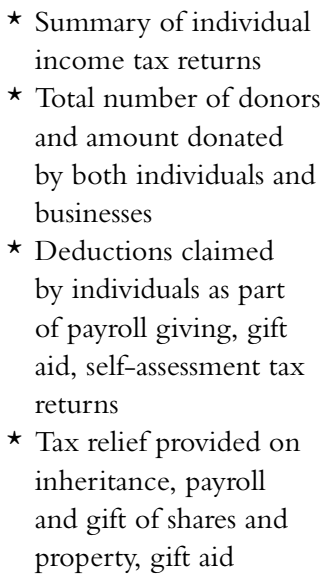 & $\begin{array}{l}\text { * Scale of donation data } \\
\text { available at the level of } \\
\text { individual } \\
\text { * Sector specific-data on } \\
\text { level of donations, for } \\
\text { example, on health, } \\
\text { education, and so on }\end{array}$ & $\begin{array}{l}\text { * Effectiveness of } \\
\text { tax incentives for } \\
\text { individuals and business } \\
\text { in terms of level and } \\
\text { number of donors at } \\
\text { different income levels } \\
\text { and charity sectors }\end{array}$ \\
\hline United States & 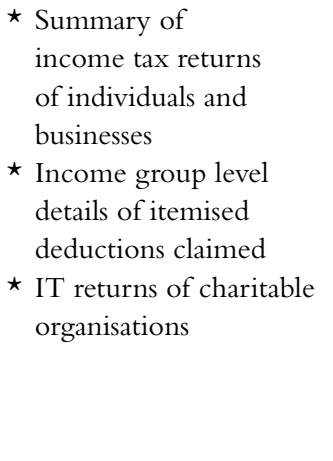 & $\begin{array}{l}\text { * Overall quantum } \\
\text { of charitable giving } \\
\text { in billion USD } \\
\text { further divided by } \\
\text { donors, individuals, } \\
\text { corporations } \\
\text { ^ Individual giving as } \\
\text { percentage of disposable } \\
\text { income and business } \\
\text { giving as a percent of } \\
\text { profit }\end{array}$ & $\begin{array}{l}\text { * Effectiveness of } \\
\text { tax incentives for } \\
\text { individuals and } \\
\text { businesses in terms } \\
\text { of level and number } \\
\text { of donors at different } \\
\text { income levels and } \\
\text { charity sectors } \\
\text { * Effectiveness of tax } \\
\text { incentives based on } \\
\text { donation data from } \\
\text { charities }\end{array}$ \\
\hline
\end{tabular}

Sources: CAF/NCVO, 2010; NCVO, 2017; HMRC, 2019; NCVO Charity Tax Commission, 2019; Giving USA, 2020; IRS, 2020; U.S. Department of the Treasury, 2020

and provides a critical feedback loop on government policies, programmes, and actions. The formalisation of civil society strengthens the state-society relationships and creates an effective ground for democratic functioning. Thus, a comprehensive study of the multiple registers at which tax incentives link the state with the non-profit sector is a first step in strengthening India's tax incentive regime for civil society.

\section{Conclusion}

Despite its widespread destruction and challenges, the COVID-19 pandemic has highlighted the urgent need for a constructive relationship between the non-profit sector and the Indian state. The need to define the contours of the legal and regulatory environment of the non-profit sector to meet the demands of the current times has never been clearer, with the tax incentive regime being a critical component. Furthermore, evaluating the contributions of tax incentives to the non-profit sector is essential to strengthening the tax regime around the specific needs of the non-profit sector. As this sector has numerous small NPOs, small donors should be incentivised or enabled to avail themselves of tax incentives more easily. It is likely that high-income 


\section{Chakravarty and Singh}

donors work with large NPOs, and therefore their incentive provisions could be modified to match the provisions for grossed-up donations like in the United Kingdom for better monetary benefits. Other types of incentives for high-income donors should be considered, for which new types of taxes such as wealth tax and inheritance tax may need to be introduced. Our analysis highlighted that although tax incentives are not the financial backbone of the non-profit sector, their removal may significantly and adversely alter the legal and regulatory relationship between the state and the non-profit sector, the consequences of which are not fully understood given the lack of research and data. Therefore, we strongly recommend that the government reconsider further removal of tax incentives and commission a rigorous study of the role of tax incentives in the non-profit sector in India.

\section{Notes}

1 Prime Minister's Citizen Assistance and Relief in Emergency Situations Fund (PM CARES Fund) has been set up as a public charitable trust. Its objective is to provide financial and other assistance and relief in the face of crisis and calamity such as COVID-19.

2 The countries are France, Norway, Brazil, Mexico, China, South Africa, India, Bangladesh, Singapore, South Korea, the United States, and the United Kingdom.

3 Each of these legal forms is governed by national and state-level acts and has different compliance requirements.

4 The study states that the distribution of NPOs registered in the GuideStar database reflects the distribution and thematic focus areas of other publicly available databases for Indian NGOs such as the Darpan database.

5 The study sampled 800 NPOs across India from a database of $3500+$ verified NGOs available with GuideStar India. All 800 NPOs were the ones which responded to the survey. The GuideStar database reflects the distribution and focus area of other publicly available databases for Indian NGOs such as the Darpan database.

6 This cohort does not include foundations.

$71 \mathrm{USD}=73.3 \mathrm{INR}$ (see https://www.xe.com/currencyconverter/convert/?Amount $=500 \% 2 \mathrm{C} 000 \& \mathrm{~F}$ rom $=$ INR $\&$ To $=$ USD).

8 Maharashtra, therefore, has a very well-developed NPO ecosystem whose NPOs receive wide recognition for their work. This is not the case with other states, although the causality is difficult to attribute.

9 An accurate assessment of the amount of tax incentivised for donations is not possible due to two prominent limitations of this data. First, the figure represents the revenue foregone by the government, which includes exemptions given to the donations made to government trusts and funds as well as other NPOs. Second, it may not include the contributions made by high-net-worth individuals because they 'typically make philanthropic contributions either independently or through a family-run foundation, and are neither required to report their philanthropic investments, nor to claim tax exemptions' (CSIP, 2020).

10 This move reduces the effective tax rate to $25.17 \%$, (inclusive of surcharge and cess) as against the existing statutory tax rate of $34.32 \%$.

11 See Chattopadhyay, 2011; Rao et al., 2016.

12 A part of this discussion is based on (Chakravarty, 2014); see (Chattopadhyay, 2011; Rao et al., 2016).

13 Long-term capital gains tax on securities has been re-introduced in the budget 2018-19.

14 These are applicable on all taxes.

15 Taxable income between INR 20 million and INR 50 million now attracts a $25 \%$ surcharge, while taxable income above INR 50 million attracts a 37\% surcharge. The surcharge rate for both taxable income groups was $15 \%$ earlier.

16 Twenty-two percent in case companies do not avail of any tax incentives.

17 That is, tax concessions of all kinds.

18 To illustrate, on a monthly salary of 1000 INR, which receives a $20 \%$ tax cut for a $100-$ INR donation, in a deduction-based tax incentive. Here, the donated amount is deducted from the pre-tax salary (1000 INR), and the tax outflow reduces from 200 INR to 180 INR if there is no tax incentive on donations. However, in a credit-based incentive, the tax outflow will reduce to 100 INR because the 
donated amount is deducted from the tax the donor will pay. In both cases, we assume that the entire amount donated is eligible for tax incentive.

19 The grossed-up donation-based approach to incentives has two components. First is the grossed-up section, in which both the amount donated and the tax applicable are given to the charity. Notably, this provision directs the revenue foregone by the government to the charity and not the donor. The donor benefits because this provision amplifies the monetary value of the amount donated. Second is the rebate component, which is applicable to high-income donors who face high (e.g., 40\%) tax rates. In this, the government pays to the donor the tax amount over and above the standard rate, that is, the difference between the higher tax rate of $40 \%$ and the standard tax rate at $20 \%$.

20 This does not include grossed-up donations in Ireland.

21 The eligible causes are only one among the many eligibility criteria for an organisation to fulfil to receive tax incentives.

22 In some countries, the causes for charitable donations differ for individuals and businesses. This table represents only the causes applicable to individual donations.

\section{References}

Agarwal, S. and Dadrawala, N. (2004) 'Philanthropy and Law in South Asia', in Sidel, M. and Zaman, I. (eds) University of Iowa Legal Studies Research Paper. Available at: https://papers.ssrn.com/sol3/papers. cfm?abstract_id=1126337.

Aggarwal, K. P. (1989) Stimulative Effect of Tax Incentive for Charitable Contributions: A Study of Indian Corporate Sector. New Delhi: National Institute of Public Finance \& Policy.

Backus, P. and Grant, N. (2019) 'How Sensitive Is the Average Taxpayer to Changes in the Tax-Price of Giving', International Tax Public Finance, 26.

Bijika, J. (2013) 'A Primer on the Empirical Evidence for the USA and Its Implications', Social Research, 80.

CAF America (2021) CAF Russia, CAF America Insider Blog. Available at: https://www.cafamerica.org/ caf-russia/ (Accessed: 21 January 2021).

CAF/NCVO (2010) UK Giving 2010: An Overview of Charitable Giving in the UK, 2009/10. Available at: https://cdoliv01sifi01.cafonline.org/docs/default-source/cafcdodocuments/UK-Giving-2010_1012 10.pdf.

CBGA (2019) Promises and Priorities: An Analysis of Union Budget 2019-20. New Delhi: CBGA.

Chakravarty, M. (2014) 'Public Finance Policy and Inequality: A Review of the Contrasting Experiences of India and Ecuador', in Flores, C. S. and Cortes, C. L. (eds) Democratic Renewal Versus Neoliberalism: Towards Empowerment and Inclusion. Buenos Aires: CLACSO (Latin American Council of Social Sciences).

Chattopadhyay, S. (2011) 'Assessing Tax Policy and Tax Compliance in the Reform Era', in Progressive Fiscal Policy in India. 1st edn. New Delhi: Sage Publishers, pp. 148-173.

Chua, V. C. and Wong, C. M. (1999) 'Tax Incentives, Individual Characteristics and Charitable Giving in Singapore', International Journal of Social Economics, 68.

Clotfelter, T. C. (2012) 'Ending Corporate Tax Avoidance and Tax Competition: A Plan to Collect the Tax Deficit of Multinationals', in Fack, G. and Landis, C. (eds) Charitable Giving and Tax Policy: A Historical and Comparative Perspective. Paris: School of Economics.

CSIP, A. U. (2019) Enabling Philanthropy and Social Impact in India. New Delhi. Available at: https://csip. ashoka.edu.in/research-and-knowledge/.

CSIP, A. U. (2020) Estimating Philanthropic Capital in India: Approaches and Challenges. New Delhi. Available at: https://csip.ashoka.edu.in/research-and-knowledge/.

DASRA (2020) Institutional Resilience and Impact Optimisation Toolkit. Mumbai: DASRA.

Duquette, N. (2016) 'Do Tax Incentives Affect Charitable Contributions? - Evidence from Public Charities’ Reported Revenues', Journal of Public Economics, 137.

Fack, G. and Landais, C. (2010) 'Are Tax Incentives for Charitable Giving Efficient? Evidence from France', American Economic Journal: Economic Policy, 117-141.

GIving USA (2020). Available at: https://givingusa.org/ (Accessed: 13 October 2020).

GOI (2001) Report of the Advisory Group on Tax Policy and Tax Administration for the Tenth Plan. New Delhi: GOI.

HMRC (2019) UK Charity Tax Relief Statistics, UK Charity Tax Relief Statistics Commentary. New Delhi: HMRC. 


\section{Chakravarty and Singh}

IRS (2020) Tax Statistics. Available at: https://www.irs.gov/statistics (Accessed: 13 October 2020).

Kulkarni, S. (2020) 'NITI Aayog Reaches Out to 92,000 NGOs for Joint COVID-19 Fight', Deccan Herald, 5 April.

Lexology (2020) China Tax Policies to Address the COVID-19 Pandemic. Available at: https://www.lexology. com/library/detail.aspx?g=8c9bab9d-c184-4268-b0a6-ae59d00569fe (Accessed: 9 November 2020).

Ministry of Finance (2020) Finance Act. New Delhi. Available at: http://egazette.nic.in/WriteReadData/2020/218938.pdf.

MOSPI (2012) Final Report on Non Profit Institutions in India: A Profile and Satellite Accounts in the Framework of System of National Accounts (including State-wise Comparison of Profiles). New Delhi: MOSPI.

NCVO (2017) Getting Involved. London. Available at: https://www.ncvo.org.uk/images/documents/policy_and_research/participation/NCVO_2017_Getting_Involved.pdf.

NCVO Charity Tax Commission (2019) UK Charity Tax Statistics Overview. Available at: https://www. ncvo.org.uk/images/documents/policy_and_research/funding/CharityCommissionResearchReport_3.pdf.

Park, M. and Jeon, B. (2017) Impact of Tax Incentives on Charitable Contribution. Korea: Institute of Public Finance.

Pattnaik, R. K. et al. (2009) Empirical Fiscal Research in India: A Survey. New Delhi: Reserve Bank of India.

Puri, A., Nayak, P. K. and Dadrawala, N. (2018) Global Institutional Philanthropy: A Preliminary Status Report; Part Two, Country Profiles, Johnson, P. D. (ed). Available at: https://www.civicus.org/images/ Southern\%20Philanthropy\%20Social\%20Justice\%20and\%20Human\%20Rights_apr2016_FINAL.pdf.

Rajakumar, D. J. and Shetty, L. S. (2020) 'Corporate Tax Reductions: Weak Analytical Foundation', Economic And Political Weekly, 10, 62-66.

Rao, M. G. and Rao, R. (eds) (2006) 'Trends and Issues in Tax Policy and Reform in India', India Policy Forum, 2.

Rao, R. K. et al. (2016) Corporate Tax: A Brief Assessment of Some Exemptions, 165. Available at: https:// ideas.repec.org/p/npf/wpaper/16-165.html.

Sampradaan Indian Centre for Philanthropy (2004) A Review of Charities Administration in India. Available at: https://niti.gov.in/planningcommission.gov.in/docs/reports/sereport/ser/stdy_cai.pdf.

Scharf, K. and Smith, S. (2009) Gift Aid Donor Research: Exploring Options for Reforming Higher-Rate Relief: A Report for HMRC and MHT. Her Majesty's Revenue and Customs. Available at: https://www.bristol. ac.uk/media-library/sites/cmpo/migrated/documents/giftaid.pdf.

Srinath, I. (2003) 'Donations and Deductions', Outlook India, March. Available at: https://www.outlookindia.com/website/story/donations-and-deductions/219358.

U.S. Department of the Treasury (2020) Tax Expenditures. Available at: https://home.treasury.gov/policyissues/tax-policy/tax-expenditures (Accessed: 13 October 2020).

VANI (2016) Income Tax Act for the Voluntary Sector - A Study Report. New Delhi. Available at: https:// www.vaniindia.org/publicationpdf/incometaxvani.pdf.

Viswanath, P. and Dadrawal, N. (2004) Philanthropy and Equity: The Case of India. Cambridge, MA: Global Equity Initiative, Harvard University. 